\title{
Storlekens \\ betydelse: \\ Förhandlingar i \\ det genetiskt imaginära
}

Af Cecilia Åsberg

Ved et narstudie af fire billeder fra popularvidenskabelige tidsskrifter, bliver der givet et signalement af det genetisk imaginare med fokus poi storrelsens symbolske betydning for maskulinitet og magt.

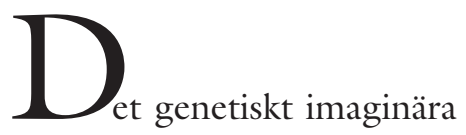
kan förstås som våra gemensamma föreställningar kring gener. ${ }^{1}$ Att de är gemensamma ska dock inte förstås som att de enkom är stereotypa och fria från motsägelser. Istället hänvisar "gemensamma föreställningar" till omstridda och kontroversiella föreställningar, exempelvis (som i denna artikel) till spänningsfältet mellan kön, sexualitet, ras och gener. Dessa föreställningar cirkuleras och omförhandlas $i$ väven av meningsskapande praktiker i vardagskulturen. Generna och det genetiska har trots sina omstridda betydelser stort förklaringsvärde i våra vardagliga föreställningar om naturlighet, sexualitet, könsbeteenden och reproduktion. Detta återspeglas också och får konsekvenser i den mikrobiologiska och medicinska forskning som görs, vilket i sin tur på olika vis kan tänkas återverka på våra kroppar. De betydelser vi tillmäter våra gener $\mathrm{i}$ dessa superdigitaliserade tider är också förankrade i den feministiskt brinnande frågan om vad vi i vår samtid förstår som natur- 
ligt. Det "naturliga” är ju i sin tur något vi ofta använder för att legitimera och rättfärdiga handlingar och tänkanden kring kön och ras.

Denna artikel tar fasta på fyra populärvetenskapliga bilder, vilka närläses som frysta scener ur våra genetiska föreställningar. Bilderna analyseras utifrån den symboliska betydelse som storlekstemat har för att iscensätta såväl maskulin dominans som maskulin regimkris i framställningarna av genetiska entiteter som exempelvis kromosomer, ägg och spermier.

\section{ATT ANALYSERA \\ GENETISKA FÖRESTÄLLNINGAR}

Materialet är hämtat från en svensk och en nordisk populärvetenskaplig tidskrift. Nedan koncentrerar jag mig på de bildliga föreställningarna av våra gener, på den visuella text- och bildvärld som återfinns i den rikt illustrerade, glättiga, svensk- och danskspråkiga tidskrifterna Forskning \& Framsteg och Illustrerad Vetenskap. Undersökningen är inspirerad av den del av det angloamerikanska fältet av Feminist Cultural Studies of Technoscience, som framförallt studerar olika populärvetenskapliga förmedlingar av natur- och teknikvetenskap. I dessa studier är dock ofta textanalysen priviligerad, varför denna studie fokuserar, inte bara traditionella bilder, utan även bildliga uttryck och visuell kultur i populärvetenskapliga tidskrifter. I vår samtid, speciellt inom de olika populärvetenskapliga uttrycken, är olika visualiseringsteknologier viktiga instrument i kampen om att skapa lärorik men samtidigt förnöjande och begärliga framställningar av vetenskap. Illustratörer och bildredigerare har ett viktigt arbete i de populärvetenskapliga tidskrifterna. Budskapet når främst läsarna genom bilderna, och en bra bild kan fănga läsarens intresse för en viss artikel, liksom en oillustrerad artikel kan komma att förbli oläst. Bilderna måste vara iögonfallande samtidigt som de på ett vetenskapligt godtagbart sätt ska represen- tera det biotekniska fenomenet. Det är en krävande uppgift för illustratören att framställa det för blotta ögat osynliga, såsom celler, kromosomer och gener. I denna artikel ligger fokus på den genetiska estetikens budskap och den huvudsakliga frågan som styr min analys är: Hur framställs generna och vilken mening ges de? Andra näraliggande frågor är: Vilka bilder och föreställningar manas fram och vilka visuella teknologier används? Vilka bilder och föreställningar florerar i det genetiskt imaginära i skärningspunkten mellan fakta och fiktion?

Populärvetenskap kan ta sig många visuella uttryck, men kan ändå påstås kommunicera vetenskap och teknik med hjälp av en genrespecifik estetik. Artikeln behandlar just den populärvetenskapliga estetiken och de visualiseringsteknologier i populärvetenskapliga tidskrifter, som i sig skapar betydelser kring gener. Syftet är att undersöka utvalda bildframställningar av gener där storlekens betydelse är ett centralt tema satt under förhandling. Detta görs metodologiskt genom att analysera det genetiskt imaginära som en teater med dramatiseringar, scener, aktörer, manus och scenografi. Det genetiskt imaginära i populärvetenskaplig form läses således som en mångfasetterad teater som genererar olika föreställningar, och de fyra tematiskt utvalda bilderna analyseras som frysta scener ur den genetiska teatern. Att se populärvetenskapens framställningar av gener som en teater är ett analytiskt grepp som Van Dijck 1998 utprovat på framförallt texter: "Popular science can be seen as a theatre, a site of performance where dramas are staged, which allow an audience to watch and interpret its content". (Van Dijck 1998, 16) Bilder, precis som texter, kan förstås som performativa element - det vill säga som föreställningar med aktörer, scener och scenografi. Men termen föreställning, som jag här använder den, vilar också på idén om kollektiva mentala projektioner inbäddade i det kulturellt imaginära - och i det här fallet det genetiskt imaginära. 


\section{STORLEKSTEMA}

Storlekstemat används här som ett analytiskt prisma. Storleksförhållanden är baserade på skalor och mått. Bland kulturgeografer har skalornas spatiala betydelser kopplats till reglering av sociala relationer och kulturell reproduktionen (Massey 1993, McDowell 2001). Skalor anger lösningen på sociokulturella makt- och intresserelationer, men avspeglar samtidigt också inbyggda konflikter och kriser. Skalorna och storlekens betydelse har förändrats eller omlokaliserats i det genetiskt imaginära i vår biomaniska samtid (Rabinow 1994:20, Franklin 2000: 192). Storlekstemat är centralt förbundet med maskulinitet i vårt kollektiva tänkande kring exempelvis penis och muskler, men i förlängningen också till kropp, identitet och samhällsmakt, därför är det också centralt för feministiskt perspektiverad dekonstruktion. Storlek används här som en symbolisk figuration, eller som en imploderad knutpunkt, ${ }^{2}$ fulladdad med olika betydelser (Haraway 1997).

Storlekstemat kan också förstås som en metonym där delen, i det här fallet "storleken", får representera helheten, exempelvis vad gäller den symboliska könsmaktsrelationen där positiv maskulinitet (i motställd relation till femininitet) är förknippat med exempelvis storhet, potens, auktoritet och andra maktindikatorer. Storlek kan alltså kopplas till könssymbolik såväl som till identitetsskapanden genom att storhet ofta symboliserar makt, pondus och handlingsutrymme, medans litenhet symboliserar outveckling, barnslighet, maktlöshet och femininitet. Uppenbarligen är detta dock normativa generaliseringar med många läckor, exempelvis vad gäller (västerländsk) fetma eller biologiska virus som, relativt människor sett, är små entiteter med massivt inflytande över våra liv (tänk på HIV/AIDS). Detsamma gäller ju även för just gener vilka inte bara är mikroskopiskt små, utan dessutom svåravgränsade entiteter vad gäller storlek och utsträckning (Fox Keller 2000). Trots detta, vilket är min hypotes, smyger sig såväl stereotypa som kontradiktoriska förståelser av kön in i de genetiska föreställningarna kring storlekens betydelse. Därför frågar jag mig (inte utan viss feministisk ironi) - vad har storleken för betydelse i det genetiskt imaginära?

\section{LIVET SJÄLVT SOM ALLTINGS MÅTT}

Utöver de vanliga åtta numren årligen, gav den svenska populärvetenskapliga tidskriften Forskning \& Framsteg år 2001 ut en essäsamling kallad Vändpunkter: Essäer om universum, livet och förnuftet. Hela tre av fem artiklar behandlar frågor om genetik eller evolution, och detta kan förstås som ett uttryck för den centrala plats som denna typ av tänkande de facto intar i vår samtid. Konstnären Kenneth Karlsson sammanställer på framsidan fem separata bilder till en ihopsatt helhet, som ett färgmässigt sparsmakat kollage. Denna typ av visualiseringsteknologi (linoleumtryck) är konstnärligt laddade och inte populistiskt glättiga (jämfört exempelvis med bilder från Illustrerad Vetenskap). Linoleumtrycken andas stilfullhet, konstnärlighet och smak - det vill säga bilderna är inte klassmässigt neutrala utan appellerar till en bildad och smakfullt konst- och vetenskapsintresserad läsekrets som den populärvetenskapligt intresserade medelklassen (Sturken \& Cartwright 2001: 48). Två av dessa bilder, vilka förekommer självständigt och ännu mer färgmässigt sparsmakade i häftet, ska vi nu först titta närmare på.

Artikeln författad av Marianne Rasmuson (professor emerita i genetik) är just illustrerad med en liggande dubbeltvinnad spiral (vi känner enkelt igen den som en DNA-spiral), mot en mörk bakgrund, med en orm (slange, på dansk) slingrande ovanför, nästan som en tredje del av spiralen. Ormen slingrar sig i riktning mot en kvinna och i "svansänden" står en maskrosliknande växt. Artikeln fungerar i sig som ett teatermanuskript där generna framställs implicit i sin högteknologiska och biovetenskapliga 


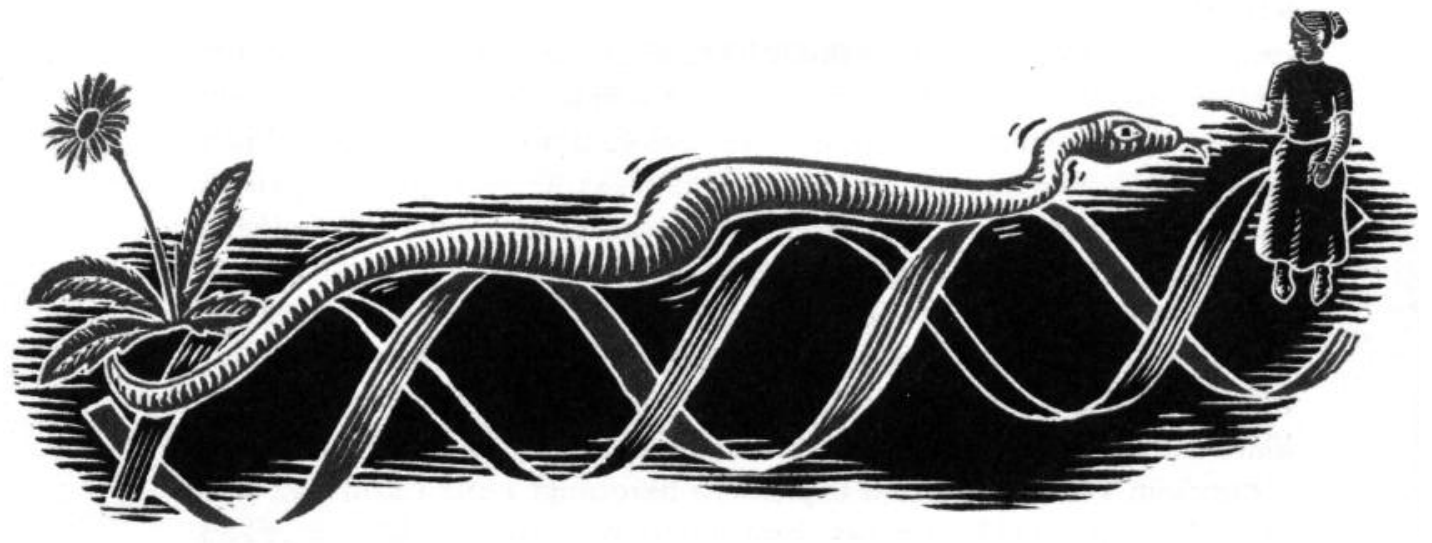

Tegning af Kenneth Karlsson, bragt $i$ Vändpunkter: Essäer om universum, livet och förnuftet 2001.

kontext. Generna som entiteter förblir dock osynliga i bilden, men gestaltas symboliskt ändå med paradoxalt nog lågteknologiska visualiseringsteknologier som linoleumtryck.

Storleken på bildens aktörer är väldigt orealistisk, då molekylen tar störst plats, sedan ormen, sedan växten och sist den på spiralen sittande kvinnan som sträcker fram en hand som för att utan rädsla klappa ormen på nosen fast hon bara äger en fjärdedel av dess storlek. Figurernas lokalisering och storleksförhållande i denna genetiska scen signalerar dock DNA-spiralens centrala och sammanlänkande position i bilden. DNA-spiralen kan förstås som att den både sammanbinder och skiljer mellan representationer av växter, djur och människor. Den fungerar sammanbindande i så måtto att alla organiska varelsers framställs som ägande en majoritet av identiska genetiska beståndsdelar, men den fungerar också skiljande genom att den hävdar att arter (och individer) ändå har något olika uppsättning gener. En tolkning utifrån DNA-spiralens storlek, dess sammanlänkande funktion och centrala lokalisering i bilden, handlar om representationer av genetisk determinism. Detta är något som artikeltexten uttryckligen avsvär sig, då den problematiserar artbegreppets funktion som en vattentät biologisk kategori. Genetisk determinism, föreställningen att vi är summan av och konsekvenserna av våra gener, kommuniceras främst genom den så konventionellt förstådda DNA-spiralen (Nelkin \& Lindee 1995, Haraway 1997). På så vis kan vi spåra en meningsmotsättning mellan den vetenskapliga artikeltexten och det allmänt vedertagna sättet att kommunicera denna vetenskap genom DNA-ikonen som får representera Livet självt och genernas universella förklaringskraft (Nelkin \& Lindee 1995 ). Läser vi bilden som en teaterscen ur det genetiskt imaginära förstår vi att aktörerna utgörs av DNA-spiralen i huvudrollen, ormen, kvinnan och maskrosen i olika biroller, i ett drama om Livet självt. (Livet sjülvt kan förstås som en universaliserande trop som frammanar föreställningar om evolution, artbildning, och en gemensam natur delad av alla levande varelser). Osyn- 
liga aktörer i detta drama är "regissörerna" såsom artikelförfattarinnan och scenografen/konstnären som försökt illustrera hennes text, liksom de mer back-stage relaterade producenterna, såsom (grafiker och redaktörer på) Forskning \& Framsteg.

En tolkningen av denna scen är att Livet självt, den liggande dubbelspiralen som dess metonym, är betydligt större än bara de varelser som befolkar scenen. Människan, eller det humanistiska studieobjektet, är inte alltings mått, som en gång DaVinci uttryckte det i en teckning (The Vitruvian Man). Istället dominerar den hyperboliska DNA-figuren scenen. Livet självt, ofta beskrivet i deterministiska och digitala termer som genetisk information, genetisk progammering eller DNA-kod, blir således alltings mått. Människan (ironiskt nog representerad av en kvinna) är mindre än Livet självt och delar sin plats i det svarta universum (bakgrunden) med flora och fauna. Kvinnofiguren är förminskad i orealistisk, men inte desto mindre betydelsebärande relation till DNA-spiralen, vilket kan tolkas som att hon är underordnad den gigantiska DNA figurationen, liksom övriga mänskligheten är underordnad sina gener. Kvinnofiguren får på så vis representera mänskligheten när det handlar om ödmjukhet och underordningen inför Livet självt.

Bilden med den kvinnliga figuren blir också sammankopplad med de övriga figurerna, även de representationer av Naturen. Det kvinnliga har också traditionellt, som hos romantiska naturalister som Carl von Linné, påståtts stå i större kontakt med naturen än det manliga (jmf. Schiebinger 1993). Motivet med kvinnan och ormen är också känt från andra mytologiska texter, som bibelberättelsen om syndafallet, vilket är en viktig en del av den kristna kulturens ursprungsmyt. Kvinnokroppen får traditionellt representera kopplingen mellan mänskligt liv, reproduktion och närheten till natur och andra djur (Haraway 1989, Schiebinger 1993). I denna scen kan linoleumtrycket som visualiseringsteknologi möjli- gen kopplas till mer stereotypa framställningar av kvinnor, djur och natur som förmögna att skapa sublima upplevelser (av $\mathrm{Li}$ vet självt) hos den civiliserade, upplyste, vite och manlige betraktaren (Bryld \& Lykke 2000). Illustrationen kan tolkas som att den innehåller motstridiga maskulina begär efter, såväl som ångest inför, den framställda genetiska determinismen liksom till sexuell reproduktion (vilket jag utforskar ytterligare i nästa bildanalys). I nästa illustration eller frysta teaterscen i den genetiska föreställningsvärlden ska jag också försöka utveckla de implikationer den manliga kompensationen för detta begär och denna ångest făr för begreppen natur och kultur.

\section{MANNEN SKAPAR KULTUR - OCH ÅTERUPPFINNER NATUREN}

En annan av essäerna i Forskning \& Framstegs häfte heter Därför åbäkar sig män mer än kvinnor och är skriven av Staffan Ulfstrand (professor emeritus i ekologisk zoologi). (Att “åbäka sig” är på danska "at skabe sig”.) Artikeln, här läst som manuskriptet till den genetiska föreställningen, är skriven i ekonomiska termer om evolutionära könscellstransaktioner och beskriver kvinnor, som passiva men kräsna köpare, och män, som aktiva men "åbäkiga", försäljare. Detta kallas för sexuell selektion inom den sociobiologiska diskursen. En bieffekt av männens försäljningsiver är att de också skapar, den (universellt konceptualiserade), “mänskliga kulturen" som den förstås som en imponerande räcka geniala manliga filosofer, konstnärer och vetenskapsmän som försöker imponera på sädescellsköparna. ${ }^{3}$

Detta är ännu en ursprungshistoria, denna gång med fokus på generna, eller snarare könscellerna som genetiska komponenter, vilka på ett metaforrikt sätt ger enkla förklaringar till hela (den manliga, vita, västerländska) kulturhistorien. Detta utgör således fonden till dramat. Bildens sceneri kan läsas som att det handlar om framsteg 


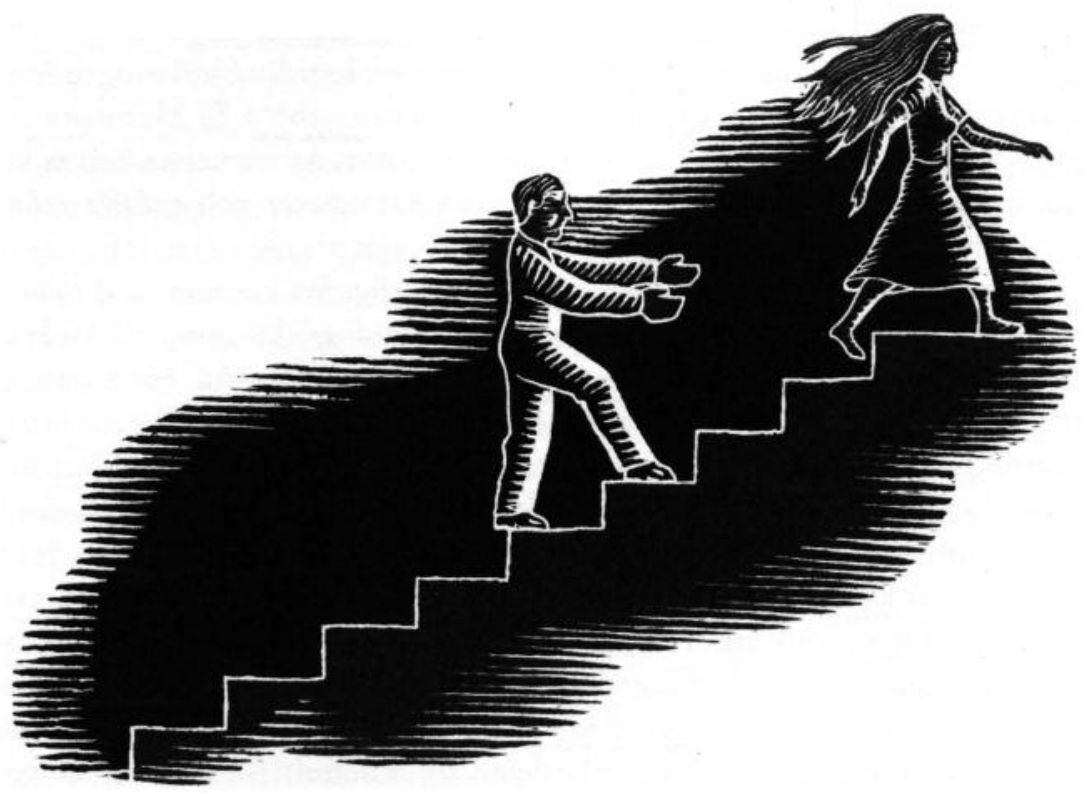

Tegning af Kenneth Karlsson, bragt $i$ Vändpunkter: Essäer om universum, livet och förnuftet 2001.

(symboliserade som trappsteg) och hur mänskligheten strävar uppför den evolutionära hierarkin genom att män jagar kvinnor. Heterosexualiteten är sömngångaraktigt självklar och gestaltas i den konstnärligt utformade illustrationen av en manlig och en kvinnlig figur. Men ska bilden tolkas som att hon går först i utvecklingsstegen och han följer efter? Det vore en annorlunda bild i det genetiskt imaginära. Oftast framställs maskulinitet kopplat till kulturbyggande och transgressiva egenskaper, och mannen ses som aktiv och ledare för utveckling och framsteg. Texten, läst som föreställningens manuskript, pekar dock snarare på en förståelse av bilden där det kvinnliga fungerar som passiv musa och inspiration, och det maskulina som en aktiv och reell driv- kraft uppåt-framåt i en teleologisk världsbild.

Dubbla mått gäller också vid gränsdragandet mellan djur och människor. Den yttre uppenbarelsen, hur hannar visar sig utåt, såsom pråliga påfåglar och hornfagra hjortar, ses ironiskt nog inte som manliga attribut, trots allt, i själva illustrationen. Där är hon den som framställs som prålig, med klänning och långt utsläppt hår som feminina attribut. Illustrationen lockar på så vis fram motstridiga tolkningar av det genetiska sceneriet; vem “åbäkar sig” mest kulturellt/genetiskt? Natur och kultur inverteras, sicksackar och faller in i varandra i en berättelse där (den manliga) högkulturen, eller till och med den västerländska civilisationen (som en del av Livet självt?), förkla- 
ras vara "naturlig": en biologisk biprodukt. Det naturliga ter sig märkligt stelt och oföränderligt, våra kulturellt och historiskt varierande föreställningar om kön blir i denna sociobiologisk tappning av det genetiskt imaginära, eviga och fastlåsta. De genetiska entiteterna är osynliggjorda i bilden, men är samtidigt betydelsefulla och utgör berättelsens primus motor. Det hela härrör nämligen ytterst från det faktum att äggcellen är större än spermiecellen.

Det är inte bara påfågelshanar som visar upp sig utan även män. Deras omedvetna syfte är att öka sin tjuskraft och få många barn. Bakgrunden är att spermier är mindre än ägg (Ulfstrand 2000: 15 ingressen).

Men denna storlekskillnad har enligt artikeln tillika genererat andra maskulint fördelade storleksskillnader; större hjärna, större "machiavellisk intelligens", större muskler, större dåd och bragder, större konst och större tankar. Storleken är här en central mekanism för maskuliniteten i dramat om Livet självt, utvecklingen och framsteget. Sammantaget framträder maskulinitetens excellens som ett resultat av spermiens kompensation gentemot äggcellens större storlek.

\section{DET GENETISKA SOM KÖNSKAMP}

Naturvetenskap och medicin har förlitat sig på diverse visualiseringsteknologier vilka också kommit att omdefiniera hur vi i allmänhet och inom vetenskap förstår den mänskliga kroppen. Kapaciteten att se in $\mathrm{i}$ kroppen med exempelvis mikroskop har därmed ändrat våra förståelser av kroppen. Att vetenskap såväl som populärvetenskap måste förlita sig på representationer och bildliga simuleringar av det studerade döljs exempelvis i bruket av avancerade datormanipulerade färgrika fotobilder; så typiska för den populärvetenskapliga genren. Visualiseringstekniker används för att visa på det abstrakta och det icke-fysiska. Dessutom bör de ha fotografiets naturalistiska och övertalande funktion. Det genetiskt imaginära bildliggörs inte enbart i konstnärliga översättningar som de grafiskt sofistikerade, som lågteknologiska, konstbilder jag studerat ovan. Sturken \& Cartwright (2002) påpekar att närsom visualiseringsteknologierna alltmer lämnat det analoga formatet för det digitala så har även våra idéer om kroppen gjort det samma, exempelvis i de digitala förståelserna av gener som lagrad kod, programmering och information.

På omslaget till Illustrerad Vetenskap $\mathrm{nr}$ 5/2002 återfinner vi en fotografiskt genererad digital bild som representerar de mänskliga könskromosomerna (hos en person med manlig kromosomuppsättning, $\mathrm{XY}$ ). Fotobilden är digitalt manipulerad exempelvis på så vis att den är dramatiskt färgbearbetad med kontrasterande svart-blå bakgrund och gul-röda kromosomer. Dramatiken förstärks av det ljus som tycks stråla ut ifrån kromosomerna. Detta dramatiska manipulationsarbete är typiskt för populärvetenskapliga fotobilder eller filmer, exempelvis de vi känner till från bilder av exempelvis himlakroppar och fenomen i rymden eller Lennart Nilssons fosterbilder. Analogin till rymden går dock längre än så, då kromosomerna (likt Lennart Nilssons fosterbilder) tycks sväva i sitt eget mikrokosmos likt viktlösa astronauter. Denna genetiska teaterscen har rubriker lika dramatiska som tabloidpressens Den kvinnliga $X$ kromosomen tar makten fràn Y-kromosomen: Mannen är en hotad art. (Manden ær en trued art.) Även de omkringliggande rubrikerna har teatraliska övertoner såsom New Orleans blir det nya Atlantis eller Inblick: Skriften skapade vair civilisation. Den propert utformade tidskriftslogotypen, där tyngd och auktoritet ligger i såväl typsnitt som i användandet av ordet vetenskap, får ge vika för en explosion av mytiska konnotationer och färgstarka biologiska illustrationer. Kromosomerna som något överlappar tidskriftstiteln, tycks slungas emot oss, men hindras av det vita staket som slutligen det med emfas (nere i högra hörnet) utskrivna Mannen är en hotad art utgör. 
Omslagsbilder är avsedda att fånga potentiella köpare och tidskriften är hårdlanserad bland såväl prenumeranter som lösnummerköpare som en veritabel bildfest, där digitala fototekniker och grälla färgsättningar hjälps åt att fantasifullt illustrera vad som är vetenskap. Detta seendets kunskapsteoretiska primat, menar exempelvis Sturken \& Cartwright $(2001,298)$ har dominerat västerländsk kultur ända sedan grekerna, och kromosombilden är en sådan voyeuristisk tripp in i vårt eget inre.

Ljuset i fotobilden av kromosomerna är riktat mot vår viktigaste identitetsmarkör mot könets mörker. Upplysning och seendet förväntas avslöja den dolda kunskapen och bilden vi presenteras med avslöjar en hemlighet som andas såväl maskulin kastrationsångest som storleksfixering. Utifrån artikeln inuti tidskriften får vi veta att könskromosomerna (hos män med XY-kromosomer) är de enda kromosomer med olika storlek och olikformade parhalvor. Utgångspunkten på bilden är presumtivt manlig (XY-kromosomer framvisas) och det är likaså ett oroande manligt storleksproblem som bearbetas. Artikeln rör sig runt det faktum att den biologiska könsidentiteten inte längre biologiskt kan anses som stabil, liksom att vad som gör en man till en biologisk man är under omförhandling. Rubriken på omslaget koncentrerar det hotfulla (truende) inslaget, något som även återkommer i artikeln. Manligheten är hotad (trued), biologiskt och maktmässigt. Att $\mathrm{X}$-kromosomen anses fylla betydligt fler genetiska betydelser än Y-kromosomen bidrar också till den utmålade hotbilden. Att manligt kön inte är en egen "art”, och än mindre en stabil kroppslig kategori, hindrar inte budskapet som varnar för feminisering. Hotet (trussel) om feminisering kommer inifrån kroppen, men bilden kan knytas analogt till föreställningar om feminisering av hela sambällskroppen; samhällelig jämställdhetsutveckling och feministiska processer finns dramatiserade som ett hot mot män och manlighetens vara. På denna ge- netiska teaterscen är aktörerna, till exempel den groteskt förkrympta Y-kromosomen, framställda som varnande exempel. X-kromosomen blir analog med feminisering, vilket i sin tur blir analogt med feminism, och feminism blir slutligen framställt som ett synbart genetisk hot i egenskap av storlek och (genetiskt) meningsskapande makt.

\section{STORLEKENS BETYDELSE \\ UNDER FÖRHANDLING I \\ ILLUSTRERAD VETENSKAP}

Den danske illustratören Rasmus Nybo är ofta anlitad av Illustrerad Vetenskap. Hans tecknade illustrationer är av humoristisk karaktär och är definitivt besläktade med den heterogena genren av tecknade serier. För att åskådliggöra abstrakta och sociala, ickefysiska och/eller mikroskopiska fenomen, krävs det ibland andra visualiseringsteknologier än de fotografiska, vilket annars ofta förekommer i populärvetenskapliga magasin av denna typ. Med illustrationer av denna karaktär reser artikeln inte samma realismanspråk som en fotografisk bild, utan istället understryks det narrativa och spektakulära i den genetiska scenen.

Läsarna måste kunna förstå humorgenren och dessutom finna bilderna adekvata och pricksäkra. Tilltalet genom (köns-)humor kanske också kan fungera avväpnande? Nybos tecknade illustration (återigen i tämligen lågteknologiskt utförande) föreställer ett veritabelt könskrig på mikronivå. Vi åser en komisk scen med karikatyrer av ett ägg och en spermie i boxningskamp där deras önskningar framställs i tankebubblor. I tankebubblorna, eller drömmarna, ser vi, liksom in i en glaskula, hur framtiden ter sig för vardera parten om denne skulle vinna matchen.

Cellernas antropomorfa och bekönade drag förstärks med hjälp av läppstift, rosett och ögonfransar (på ägget) och plåster, boxhandskar och tankebubblor (på både spermie och ägg). Detta är dock ett fenomen som inte enbart finns inom populär- 

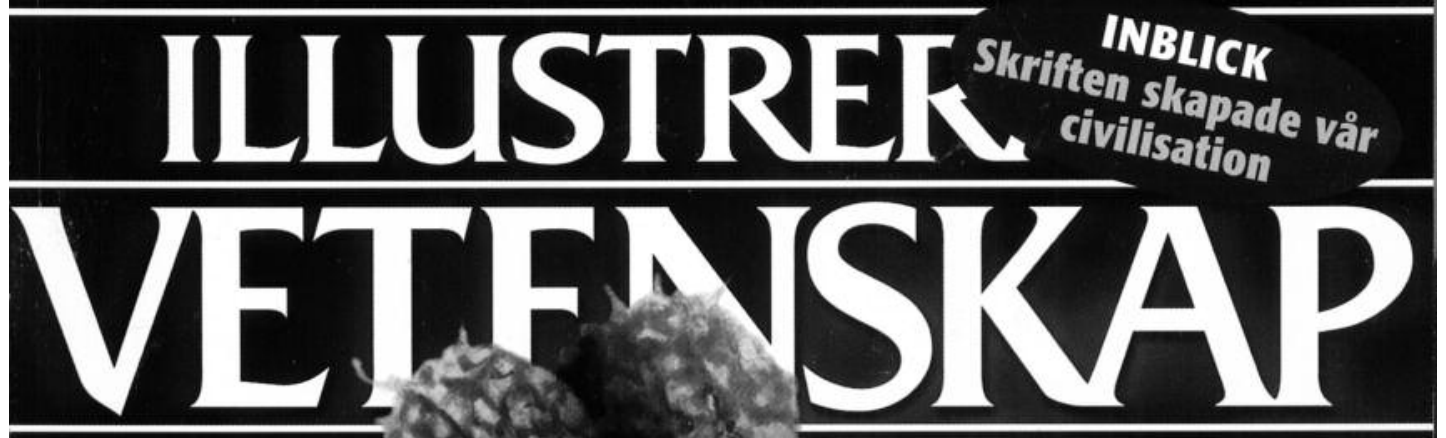

Internet skall lära sig se och höra

New Orleans blir det nya Atlantis

Japan leder kapplöpningen om den nya Concorden
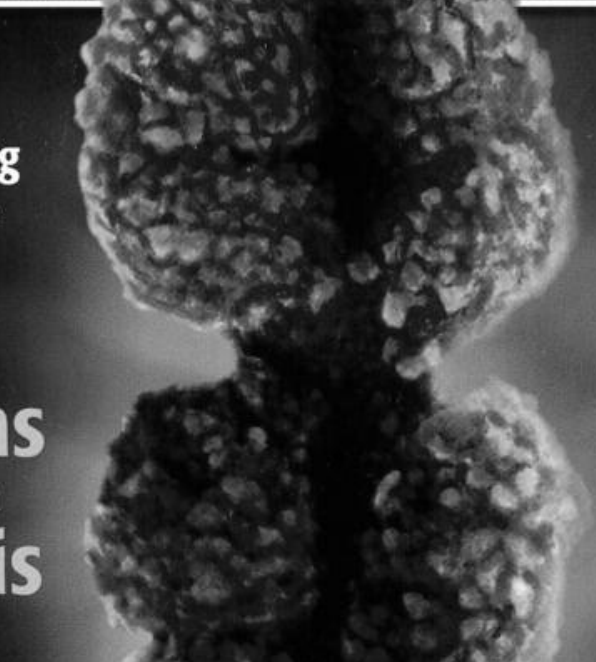

\section{en}

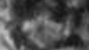


kultur. Tilldelningen av stereotypa könsroller till celler har studerats inom den biologiska vetenskapsdiskursen av bland annat Emily Martin (1991). Spermien är dimensionellt mycket förstorad i relation till ägget och är nästan hälften av äggets storlek, vilket är en intressant uppförstoring i relation till spermiers mikroskopiska storlek (Äggcellen är kroppens största cell och den är precis skönjbar med blotta ögat). Trots att hälften av alla spermier bär på kvinnliga gonadanlag, framställs spermien, som så ofta populärkultuellt, som manlig.
De antropomorfa cellernas respektive tankebubblor förmedlar två diametralt motsatta förslag. Om ägget vinner, tycks ägget tänka sig en framtidsbild med en leende blond och vithyad kvinna i röd kvinnligt skuren klänning och högklackat. Hon utstrålar nöjdhet med uttrycksstreck runt huvudet som vi känner igen från andra konventioner kring tecknade serier. Hon bär ett normaldimensionerat barn på armen, har fylliga bröst och en återigen stor och gravid mage som hon välbehagligt tycks klappa. Bredvid henne befinner sig en man

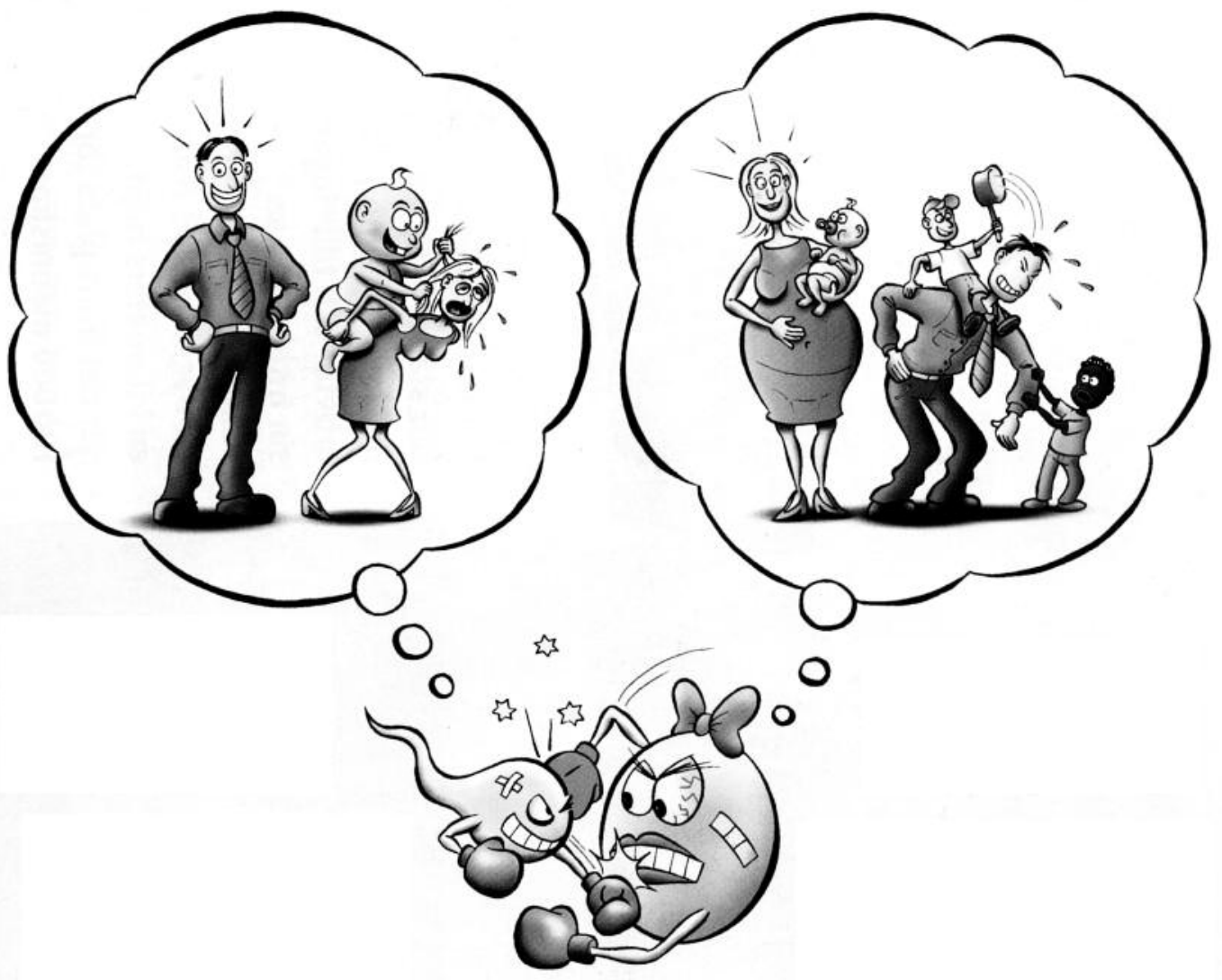

Tegning af Rasmus Nybo, bragt $i$ Illustrerad Vetenskap 2002/11. 
i blå skjorta, bruna byxor och slips som inte verkar ge uttryck för samma harmoniska föräldralycka, utan som tvärtom tar sig för den krumma ryggen. Anledningen är de två krävande småpojkarna som dels drar honom i armen, dels terroriserar honom med att sittandes på hans axlar slå honom i huvudet med en kastrull. Mannen är också vithyad, vilket gör att pojken som drar honom $\mathrm{i}$ armen signalerar skillnad och marginalitet genetmot sina vita sociala föräldrar och genom att den mörkhyade pojken illustrativt inte har den vite mannen till far. Bildtexten bekräftar tolkningen:

Vinner hennes gener, blir barnet mindre. Därför kan hon strax gå på jakt efter en ny pappa med bättre arvsanlag.

Den svarta pojken făr signalera rasskillnad samt en okänd och främmande härkomst med sina stereotypt karikerade rasdrag. Ångest över rasblandning och de biologiska kategoriernas sönderfall, är också några ingredienser som mixas i denna genetiska komediframställning. Det genetiskt imaginära är alltså inte bara invävt i köns- och sexualitetsproblematiker utan även i rasoch nationalitetsfrågor.

Kvinnofiguren blir i bilden exotiserad och underförstått promiskuös eftersom hon uppenbarligen haft sex med andra män än den avbildade vite mannen. Spermiens tankebubbla illustrerar också ett framtida scenario där istället "mannens gener" vinner. I detta scenario står samme vite man med samma kläder istället rakryggad och bakåtlutad, nöjd och brett leende med händerna i sidorna. Ovanför huvudet ser vi strecken som signalerar utstrålningen av en känsla av nöjdhet. Bredvid mannen står kvinnan uppenbarligen knäandes och böjd under sin enorma börda av en jättebebis som hon bär på ryggen. Bebisen, som är hälften av hennes storlek och betydligt kraftigare än henne, drar henne i håret, och vi förstår också på de symboliska svettdropparna och det parodiskt medtagna ansikt- suttrycket, att hon lider under sin börda. Bebisen är i detta fall ytterst nöjd, glad och aktiv, medan barnet i ägg-vinnar-scenariot är liten, tystad med napp och avbildad i passivitet. Budskapet som förmedlas i denna dramatisering av könskampen på cellnivå innehåller två paradoxer innanför den naturaliserade könsdiskursen.

Den första framställningsparadoxen handlar om sexualitet och att män innanför ett evoultionärt-biologiskt paradigm tillskrivs en aggressiv, erövrande och kvantitativ heterosexualitet. Här är det snarare så att kvinnlig sexualitet är den kvantitativt inriktade (med många barn), vilket riktar uppmärksamheten mot fascinationen och skräcken inför kvinnlig sexualitet som något kroppsligt och monstruöst med siktet inställt på reproduktion. Med ångestladdad manlig heterosexualitet projicerad på bilden av ägget som en vamp eller någon annan femme fatale figur, kan kvinnlig sexualitet beskrivas som förgörande och mansslukande. Martin (1991) beskriver att (när upptäckter gjordes som erkände äggets aktiva roll i befruktningen) de positiva kopplingarna till aktivitet som gjorts med spermier inte överfördes på ägget. Istället beskrevs ägget i negativa termer som en mansslukande femme fatale figur. Liksom de vetenskapliga diskurserna, uppvisar denna populärvetenskapliga bild en oförmåga att framställa kvinnligt konnoterad kroppslig aktivitet som något positivt.

Paradoxen ligger alltså i det att evolutionärt-genetiskt brukar den naturaliserade hållningen till manlig sexualitet vara att män, som det svenska uttrycket lyder, “måste få så sin vildhavre", medan det här är den kvinnliga figuren som framställs som den sexuellt promiskuösa (just också med den negativa laddningen). Detta eftersom hon har barn med andra män än den vite huvudrollsinnehavaren i könskampsbilden. I spermiedrömmen, där manlighetens gener segrar, har mannen, förvånande nog, inte avbildats som ånyo sexuellt aktiv vilket den evolutionära genetiska könsrollsbesätt- 
ningen brukar anföra. Istället är han märkbart opåverkad av såväl sexuell aktivitet som reproduktiv aktivitet. I äggdrömmen är hon dock inte "fri", ensam eller obunden, utan gravid med överdimensionerad mage och fylliga bröst, samtidigt som hon redan har en liten på armen. Äggdrömmen förser oss med föreställningen av de "kvinnliga genernas" högsta önskan; att reproducera sig kvantitativt (istället för ett "rejält" och kvalitativt barn: många små) .

Detta för oss över till den andra implicerade paradoxen innanför den genetiska pantomimscenen. Den genetiska teaterns föreställningsvärld rymmer också idén om ägg som en "kvalitativ produkt" (drygt 400 mognade ägg per kvinnlig livstid jämfört med oräkneliga antal spermier). Spermier framställs ofta antalsmässigt positivt, som en härskara av krigare som attackerar ägget, belägrar och penetrerar det (Martin 1991). Kvantitet är i vilket fall en positiv term som vidhäftar bildliggörandet av manlig sperma (Martin 1991, 488).4 Relationerna är dock de omvända i Illustrerad Vetenskaps genetiska föreställning. Om hans gener får bestämma blir det kvalitet på barnet ("framgångsrik avkomma"). Om hennes gener får bestämma blir avkomman däremot markant mindre samt mer passiv. Egenskaper som kvalitet och kvantitet, och grad av sexuell aktivitet, ges alltså biologiskt flexibla betydelser som till övervägande del tillskriver män och manlighet den positiva sidan, oberoende av kontexten.

\section{STORLEKENS BETYDELSE OCH \\ MASKULIN ÅNGEST I GENETISKA \\ FÖRESTÄLLNINGAR}

Meningsskapanden kring storleksförhållanden har följts upp tematiskt i fyra bilder, lästa som frysta teaterscener, ur det genetiskt imaginära som innehållit förhandlingar om genernas betydelse. Natur-kultur distinktionen omförhandlades i de genetiska föreställningarna. Den bakomliggande orsaken, knuten till maskulin ångest, var frågan om storleksförhållandena när det kommer till kön. Att vara "störst" och mest "kvalitativ" verkar vara det manliga kromosom- såväl som könscellsbegäret, egenskaper som annars på ett hotande sätt tillskrivits de kvinnliga könscellerna och X-kromosomen. Dessa flytande egenskaper inskrivs också på slutprodukten av könskriget, nämligen barnet som, förutsatt att det manliga genetiska vunnit, blir stort. Storleksförhållanden har på så vis omförhandlats, reverserats och omlokaliserats, men ändå bibehålls ramen av "naturlighet" kring de genetiska scenerna. Slutsatserna angående storlekstemat kan, ur ett feministiskt perspektiv på de fyra frysta genetiska scenerna, sammanfattas:

- DNA-ikonen görs till en storleksmetonym för Livet självt, förstått så som en universalistisk, bombastisk och deterministisk genetisk kosmologi.

- Evolutionärt-teleologiskt rationalitet bygger på den sociobiologiska idén om maskulin kulturell drivkraft, då spermien kompenserar sin mindre storlek i relation till ägget.

- Stora “kvinnliga” äggceller och X kromosomer utgör ett dramatiserat hot (trussel) mot manlig identitet, små "manliga" spermier och förkrympta Y kromosomer.

- Analogt med det kroppsliga hotet om biologisk feminisering, dramatiseras också ett feminiseringshot mot samhällskroppen i form av jämställdhet och feminism. Manlig identitet som kroppsligt (och samhällsmässigt) överordnad kategori är ifrågasatt och satt under förhandling.

- I föreställningarna tillskrivs ena gången kvinnor hög grad av sexuell och reproduktiv aktivitet och i nästa tillskrivs män detsamma. Det kvalitativa ("stora/singulära") och det kvantitativa ("lilla/pluralistiska") växlar som sätt att beskriva kvinnligt och manligt.

- De populärvetenskapliga bilderna uppvisar en oförmåga att framställa kvinnligt konnoterad kroppslig aktivitet som något 
positivt, oavsett om det gäller kvantitet eller kvalitet, låg eller hög sexuell-reproduktiv aktivitet.

- Samtliga frysta genscenarion är såväl köns- som rasmarkerade och därmed också kulturgeografiskt markerade och historiskt daterade. Dock kan dessa uttryck också, i dessa speciella scenarion, utläsas som identitetsmarkörer satta under omförhandling vad gäller deras "naturliga" status innanför den genetiska representationsteatern.

Meningsskapandet kring storlekens betydelse i det genetiskt imaginära, läst som teaterföreställningar, har visat sig innehålla såväl stereotyper som paradoxer kring kön och storlek. Genetiska manifestationer i form av kromosomer och könsceller beskrivs ofta i stereotypt könade och antropomorfa former. Fantasier, föreställningar och betydelseladdade symboler är vad vi mötts av i illustrationerna, vilka också säger oss något om hur mening skapas kring gener och att dessa förhandlingar är allt annat än könsneutrala. Därmed inte sagt att de genetiska scenerna var alltigenom stereotypa, utan de innehöll både överskjutande mening och paradoxer som destabiliserar föreställningar om kön. Illustrationerna är kanske $\mathrm{i}$ första hand ämnade att representera innehållet i respektive artikel, men de visualiserar också imaginära och fantasiladdade föreställningar om det genetiska och om kön. Avslutningsvis har storlekens bekönade betydelser här exponerats och visat sig ha bäring på framställningarna av det genetiska i populärvetenskapliga bilder. Kulturellt kön färgar av sig på våra föreställningar om det genetiska och biologiskt kön. Så med ett snett (skævt) feministiskt smil kan jag konstatera att även i det genetiskt imaginära har storleken betydelse.

\section{NOTER}

1. Genernas kulturella betydelser är fristående från biologiska definitioner. Generna är till vardags snarare ett smidigt sätt att vardagligt definiera identitet och släktskap på ett meningsskapande sätt (Nelkin \& Lindée 1995, 16). Termer som "genetisk information", "DNA-kod" och "genetisk programmering" är ett uttryck färgat av samtidens datorisering, där generna uppförstoras till hyperbolen Livet självt, vilker förstås som ett gigantiskt genealogiskt informationssystem (Franklin 2000:194). Ikonen, framför andra bildliga representationer av Livet självt, innanför den genvetenskapliga ramen utgörs populärkulturellt av DNA-spiralen (Nelkin \& Lindée 1995).

2. Donna Haraway (1997) pratar om imploded knots, vilket jag här översätter till imploderade knutpunkter med vilka avses betydelseladdade figurer i vår samtid (såsom fostret, genen och neuronen).

3. Det är ingen slump att begreppen och termerna inom de sociobiologiska begreppsvärlden utvecklades i historisk samklang med den neo-klassiska nationalekonomin. Den sexuella selektionen, vilken artikelförfattaren beskriver, är reducerad till neoklassiskt ekonomiska begrepp som utbud och efterfrågan. Mesta möjliga vinst, för minsta möjliga energimängd, nyttomaximering, investering, konkurrens och andra marknadsmetaforer genomsyrar också det genetiskt imaginära. Ett grundantagande är att alla tävlar på lika villkor, bara med olika strategier, i det enda spelet som verkligen räknas; nämligen det att samla genetisk profit. Beteenden är då som evolutionens pacemaker, skriver Haraway (1991, 62). Fantasi, tänkande och kulturella praktiker blir också på så vis reducerade till genetiska strategier för vinstmaximering $\mathrm{i}$ ett spel där brist och tävlan om resurserna är centrala element.

4. Tidigare forskning om det genetiskt imaginära i populärvetenskap visar att bilderna som ges av exempelvis ägg och spermier är indragna i populärkulturella, såväl som vetenskapliga, stereotyper av hur kvinnor och män är eller förväntas betee sig (Fausto Sterling 1985, Martin 1991, Haraway 1991). Det sker alltså en växelverkan mellan föreställningarna om natur och kultur vad gäller kampen om vad kön innebär genetiskt sett, så att mening hämtas från kulturen och i nästa stund återanvänds för att legitmiera det "naturliga" (Fausto Sterling 1985, Franklin 1997, Bousé 2000). 


\section{REFERENSER}

- Bryld, Mette \& Lykke, Nina (2000): Cosmodolphins. Feminist Cultural Studies of technology, Animals and the Sacred. London, New York: Zed Books.

- Bousé, Derek (2000): Wildlife Films, Philadelphia: University of Pennsylvania Press.

. Creed, Barbara (2000): "Alien and the Monstrous-Feminine" i: The Gendered Cyborg. London, New York, Routledge.

- Fausto Sterling, Anne (1985): Myths of Gender. Biological Theories About Women and Men. (Rev. Second Edition 1992), New York: Basic Books. - Franklin, Sarah (1997): Embodied Progress: A cultural account of assisted conception, London \& New York Routledge.

- Franklin, Sarah, Celia Lury \& Jackie Stacey (2000): Global Nature, Global Culture, London, Thousand Oakes, New Delhi: Sage.

- Fox Keller, Evelyn (2000): Century of the Gene. Cambridge, London: Harvard University Press.

- Haraway, Donna (1989): Primate Visions: Gender, Race and Nature in the World of Science, New York \& London: Routledge.

- Haraway, Donna (1991): Simians, Cyborgs, and Women. The Reinvention of Nature. New York: Routledge.

- Haraway, Donna (1997): Modest_Witness@Secon_Millenium. FemaleMan $\bigodot_{-}$Meets_OncoMouse ${ }^{\mathrm{TM}}$. Feminism and Technoscience, New York \& London: Routledge.

- McDowell, Linda (2001): "Linking scales: or how research about gender and organizations raises new issues for economic geography", in Journal of Economic Geography 1 (2001) s. 227-250. Oxford University Press.

- Massey, Doreen (1993): "Power geometry and a progressive sense of place." I: J. Bird, B. Curtis, T. Putnam, G. Robertson \& L. Tickner (red.) Mapping the Futures. London: Routledge.

- Martin, Emily (1991): “The Sperm and the Egg: How Science has Constructed a Romance Based on Stereotypical Male Female Roles", in Signs $16: 3,1991$.
- Nelkin, Dorothy \& Lindee, Susan (1995): The DNA Mystique: The Gene as a Cultural Icon, New York: W.H. Freeman.

- Palmgren, Gorm (2001): "Mor och far i öppet genkrig", in Illustrerad Vetenskap, nr 11/2001. - Rabinow, Paul (1994): "Introduction: a vital rationalist", in Delaporte (red.): A Vital rationalist: selected writings from Geoges Canguilhem, New York: Zone.

- Rasmusson, Marianne (2001) "En art är inte helt enkelt en art", in Vändpunkter: Essäer om omuniversum, livet och förnuftet. Forskning \& Framsteg. - Schiebinger, Londa (1993): Nature's Body: Sexual Politics and the Making of Modern Science, London: Pandora.

- Sturken, Marita \& Cartwright, Lisa (2001): Practises of Looking. An Introduction to Visual culture. Oxford University Press.

. Ulfstrand, Staffan (2001) "Därför åbäkar sig män mer än kvinnor", in Vändpunkter: Essäer om omuniversum, livet och förnuftet. Forskning \& Framsteg. - Van Dijck, José (1998): ImagEnation. Popular Images of Genetics, London: Macmillan Press Ltd.

\section{SUMMARY}

The genetic imaginary can be thought of as our common imageries of genes (Van Dijck 1998). The article investigates select images (from Nordic popular science magazines) of genes where size is a central theme. The investigation is based upon analysis of the genetic imaginary as a theatre with dramatisations, scenes, actors, scripts and stagings. The theme of size put onto the genetic imageries is considered a symbolic configuration loaded with clashing and contradictory meanings about genes and genetics.

Cecilia Åsberg, doktorand ved Tema Genus, Institutionen för Tema, Linköpings Universitet 